\title{
European Coasts, Shores, and Banks, Widely in Jeopardy
}

'The economic crisis, however serious, must not prevent the introduction of stringent measures for environmental protection. Damage to the environment in Europe is already so great that we can no longer postpone action if we want to pass on to our children and grandchildren a habitable continent,' said Dr Karl Ahrens, President of the Parliamentary Assembly of the Council of Europe, in Athens, Greece, on 25 April 1984. The occasion was when, after Vienna (in 1973), Brussels (in 1976), and Berne (in 1979), the Environment Ministers of Council of Europe member countries met in Athens from 25 to 27 April 1984 to discuss European cooperation in the field of environmental protection.

This 4th European Ministerial Conference on the Environment brought together Ministers and Senior Officials from the 21 Council of Europe member countries and Finland, as well as representatives of the EEC Commission and the main international organizations concerned. The urgent need to protect Europe's banks and shores, and the introduction of a policy for integrating ecological considerations into any economic development scheme, were the central themes of the discussions, which were based on a report by the Greek delegation entitled:

Coastal areas, river-banks, and lakeshores: their planning and management in compatibility with the ecological balance:-Available from the undersigned is a detailed description-with statistics appended-of the present state of coastal areas, banks of watercourses, and lakeshores, in Council of Europe member states. In these sensitive areas, development has often resulted in the deterioration, and even destruction, of various ecosystems, especially of estuaries, wetlands, beaches, and forests. A Policy Guide then suggests a set of measures based in particular on the principle of taking environmental factors into consideration in all economic and land-use planning.

Taking as their starting-point the French delegation's study on 'The Law Applicable to Coastal Areas, Riverbanks and Lakeshores', the Ministers also discussed the legal aspect, in other words the steps that are needed to ensure better protection for these areas. Although the differences between legal systems make any comparison tricky, all European countries are clearly confronted with much the same problems. Their coasts, riverbanks, and lakeshores, face the same threats and dangers: inadequate control over tourism, urban growth, establishment of polluting industries, mineral extraction, etc. Most countries' legislation is too fragmented to cope with these dangers, and offers a good illustration of the multiplicity of interests competing over the coastline.

Action should be taken to demonstrate the relationship between protection of the environment and economic development:-This message from the Ministers at their conference in Athens means that:

-environmental policy should be an integral part of economic policy;

- environmental resources should be seen as the basis and the limiting factor of economic development;

-the cost of protection measures should be regarded as inseparable from general development costs; and

- protection of the environment can be instrumental in economic recovery.

These basic principles, developed over the last decade, should now be implemented and integrated into the policy-making process. They underlie the Policy Guide to which the Ministers urged Governments to pay heed when implementing their policies for the conservation of coastal areas, river-banks, and lakeshores.

\section{Hayo H. Hoekstra, Head \&}

FRANÇOISE TONDRE

European Information Centre for Nature Conservation Council of Europe Secretariat General

Boîte postale 431 R6

67006 Strasbourg Cedex

France.

\section{Frank Statement of the Agriculture Minister of Zimbabwe}

During the recent UN Economic and Social Council (ECOSOC) debate on Africa, Mr Dennis Norman, Minister of Agriculture of Zimbabwe, said in Geneva on 16 July that there was an alarming deterioration in the food situation in Africa. Food production per head of the population, which fell by $7 \%$ during the 1960 s and $15 \%$ in the 1970s, was continuing on a downward trend. There was growing incidence of rural poverty, and scarce foreign exchange reserves were being used for food imports. There were many areas of malnutrition and the problems were recently exacerbated by widespread drought. Losses from two years of drought were estimated at $\$ 575$ millions in the most-affected countries, and additional costs incurred to minimize the effects of drought were about $\$ 345$ millions. Recovery projects would cost $\$ 301$ millions, taking the total bill up to $\$ 1.221$ thousand millions.

The main problems in Africa were falling food production and increasing populations, though the situa- tion could be contained and even reversed if Africa's resource-base and land-area were taken into consideration. Africa was not yet over-populated. Africa was also blessed with good river systems and catchment areas.

Although it appeared to be too late for some countries which were already severely hit, the Minister remained optimistic because of the existing resource-base in Africa. The needs were for new policies, new investments, and joint ventures, before total degradation and misery became the norms. If the present trend to food deficits could be reversed, many of Africa's economic ills would fall away or diminish. 